\title{
Interactive effects of timing, intensity and duration of experimental shading on Amphibolis griffithii
}

\author{
Paul S. Lavery ${ }^{1, *}$, Kathryn McMahon ${ }^{1}$, Michael Mulligan $^{2}{ }^{\text {, Andrew Tennyson }}{ }^{1}$ \\ ${ }^{1}$ Centre for Marine Ecosystems Research, Edith Cowan University, 270 Joondalup Drive, Joondalup WA 6027, Australia \\ ${ }^{2}$ Geraldton Port Authority, PO Box 1856, Geraldton WA 6531, Australia
}

\begin{abstract}
The responses of the seagrass Amphibolis griffithii to different experimental shading conditions were examined by characterising biomass, morphological and physiological features. In an in situ experiment, the intensity (ambient, moderate shading [13 to $19 \%$ of ambient] and high shading [ 5 to $11 \%$ of ambient]), duration $(3,6,9 \mathrm{mo})$ and timing (post-summer, post-winter) of light reductions were manipulated. We observed interactive effects of all 3 factors, the most notable being with timing. When moderate shading was imposed at the end of summer there was a $57 \%$ loss of leaf biomass and $67 \%$ loss of rhizome carbohydrates within 3 mo. The same shading imposed at the end of winter caused no loss of leaf biomass and only a $25 \%$ decline in rhizome carbohydrates. This contrasting effect of time reflects the plant's photo-physiological characteristics under the water temperature and light conditions. More prolonged or higher intensity shading produced more consistent responses at both times of year: moderate shading resulted in more than $93 \%$ loss of leaf biomass after 9 mo and high intensity shading resulted in more than $99 \%$ loss after 9 mo. The results highlight the importance of time of year when attempting to predict seagrass responses to shading. The study identified 14 potential early indicators of light reduction; these included leaf $\delta^{15} \mathrm{~N}$, which may reflect changes in the allocation of nitrogen in the photosynthetic apparatus. There is no evidence that A. griffithii is more susceptible to shading than larger seagrasses such as Posidonia spp.
\end{abstract}

KEY WORDS: Light reduction $\cdot$ Dredging $\cdot$ Seagrass disturbance $\cdot$ Australia

\section{INTRODUCTION}

Light is among the most important environmental factors controlling coastal benthic primary productivity. Reduced availability of light has been repeatedly implicated in the decline of seagrass meadows worldwide (Longstaff \& Dennison 1999, Ralph et al. 2006). Significant causes of reduced light availability are eutrophication, sedimentation and dredging activities (Walker \& McComb 1992, Duarte 2002). Given the increasingly acknowledged value of seagrass ecosystems (Green \& Short 2003, Orth et al. 2006), there has been growing interest in understanding their responses to changes in light climate, quantifying their minimum light requirements and identifying early indicators of reduced light. Most of that research has focussed on a few species, particularly those of Posidonia (Gordon et al. 1994, Ruiz \& Romero 2003, Collier et al. 2009), Zostera (Dennison \& Alberte 1982, Abal et al. 1994) and small, fast-growing, tropical species (Longstaff \& Dennison 1999). Typically, these species respond to reduced light availability through morphological and physiological changes that may allow the plant to maintain a neutral or positive carbon-budget (Touchette \& Burkholder 2000) by reducing the draw on storage reserves (Peralta et al. 2002) or decreasing self-shading in the canopy (Carruthers \& Walker 1997, Collier et al. 2009).

Mackey et al. (2007) described the response of Amphibolis griffithii to reduced light availability but only for a single intensity of shading over a short period in 1 season. In reality, reduced light availability can be dri- 
ven by a variety of events over highly variable timescales. Dredging operations in Geraldton Port, Western Australia, in 2003 illustrate this as they produced a sediment plume of approximately $140 \mathrm{~km}^{2}$ that persisted for over 9 mo. Over several tens of $\mathrm{km}^{2}$ (Geraldton Port Authority unpubl. data), photosynthetic photon flux density (PPFD) was reduced by more than $90 \%$ relative to ambient conditions, leading to the death of Amphibolis spp. and severe reductions in biomass in a larger surrounding area. Over this time and area, plants were subjected to varying degrees of shading, from negligible to more than $90 \%$ reduction of ambient sunlight, and from a few weeks at the periphery of the plume to 9 mo close to the dredging activity .

Thus shading events can vary in intensity and duration and can occur at different times of year, superimposed on seasonal differences in ambient light availability and seasonal patterns in plant physiology (Touchette \& Burkholder 2000). In the context of understanding the potential impacts of human-induced light reductions, quantitative assessments of the degree of shading that can be sustained without irreversible or long-term damage are urgently required. To date, no study has examined the interactive effects of different intensities, durations and timings of shading on seagrasses.

We undertook a field experiment with the aim of determining the interactive effects of intensity, duration and timing of shading on Amphibolis griffithii. We also aimed to identify variables that responded to shading and had the potential to serve as indicators of light reduction in A. griffithii canopies. A. griffithii is endemic to southern and western Australia, where it is a dominant keystone species forming meadows in shallow coastal waters. The plants are 30 to $100 \mathrm{~cm}$ tall with a relatively thin horizontal rhizome that branches vertically into 'stems' (Ducker et al. 1977). Clusters of 3 to 5 leaves are situated along terminating ends of the branching, lignified stems (Marba \& Walker 1999). Partly due to its relatively thin rhizomes and, potentially, lower capacity to store carbohydrate reserves, Amphibolis is placed towards the centre of the seagrass functional-form model (Walker et al. 1999), implying a lower resilience to disturbance but, also, greater capacity for recovery compared to the larger seagrasses, such as Posidonia species. We hypothesised: (1) Relative to larger seagrasses, A. griffithii would be less tolerant of severe shading due to its thin rhizome structure and presumed low capacity to store carbohydrate reserves. (2) Changes in the seagrass canopy would be proportional to the magnitude and duration of shading. (3) The time of year of shading would be significant through its effect on ambient environmental conditions and possible shifts in plant photo-physiology.

\section{MATERIALS AND METHODS}

Experimental design. The effect of the 3 factors intensity, duration and timing of shading was experimentally tested in an extensive ( $>6$ ha) meadow of Amphibolis griffithii in $4.5 \mathrm{~m}$ water depth at Jurien Bay, Western Australia (30² 18' 34" S, $115^{\circ} 00^{\prime} 26^{\prime \prime} \mathrm{E}_{\text {; }}$ WGS84 datum).

The levels within each factor were: intensity of shading-control (i.e. ambient light), moderate and high shading; duration of shading - 0, 3, 6 and 9 mo (the 0 being measurements made before shading was commenced); and timing of shading-post-summer and post-winter. Post-summer treatments were initiated at the end of the austral summer (March) and extended through autumn (3 mo duration), autumn and winter (6 mo) or autumn to summer (9 mo; Fig. 1). Post-winter treatments were initiated at the end of the winter (September) and extended through spring, spring \& summer, and spring, summer \& autumn for the 3,6 and 9 mo treatments, respectively.

The degree of shading and the duration were selected to cover the upper range of light reduction encountered during large, commercial dredging operations, e.g. the Geraldton Port Expansion Dredging Operation (Geraldton Port Authority unpubl. data). Intensity treatments mimicked increased attenuation of ambient light due to a suspended sediment plume, rather than attempting to create a specific PPFD at the seagrass canopy. Thus, $80 \%$ shading produced a different absolute light level in winter than in summer, due to different ambient light climates. However, the treatment effectively mimics the same event (an increase in suspended sediments). As in previous studies (Bulthius 1983, Collier et al. 2009), attempts to establish procedural controls, with monofilament net suspended from the pickets, proved futile; they fouled rapidly with epiphytic algae, resulting in a 20 to $30 \%$ light reduction after a few days.

We established 5 replicate plots of each treatment in a fully orthogonal design $(n=120)$. At the end of 3,6 or 9 mo the plots allocated to that duration treatment were sampled and then terminated thus the plots for each duration were truly independent and not measured repeatedly.

The method used was similar to that of Mackey et al. (2007). Plots measuring $4.5 \times 3 \mathrm{~m}$ were constructed from 6 reinforcing bars ( $2 \mathrm{~m}$ long, $12 \mathrm{~mm}$ diameter) over which a plastic frame was threaded and positioned about $1.2 \mathrm{~m}$ above the sediment. The light reduction treatments were created by attaching highdensity polyethylene shade cloth to the frame: $50 \%$ attenuating shade cloth for moderate and $80 \%$ shade cloth for high shading. Actual shading produced was greater than the percentage values indicated by the 
manufacturer, possibly reflecting the nominal rating scale used by the manufacturer, fouling effects and differences in light reduction properties of the material for light wavelength in water compared to in air. The shade cloths were replaced every 3 to $6 \mathrm{wk}$ to prevent excessive fouling. An effective sampling area of $3 \times 1.5 \mathrm{~m}\left(4.5 \mathrm{~m}^{2}\right)$ was chosen to avoid the effects of incident light, which encroached $0.75 \mathrm{~m}$ into plots on all 4 sides (Mackey et al. 2007). The treatment plots were laid out in a grid within the meadow, with $3 \mathrm{~m}$ spacing between neighboring plots. Time 0 samples were collected before the experiment began from random locations within the meadow, but outside of the plots. Post-summer treatments were established in March 2005 and post-winter treatments in September 2005 , with treatment plots located randomly within the grid at each time.

Parameters measured. Photosynthetic Photon Flux Density (PPFD) and water temperature: PPFD reaching the top of the seagrass canopy in 1 plot from each treatment (Intensity $\times$ Duration) was measured using 'Odyssey Dataflow' submersible incident light sensors, with an automated wiper unit cleaning the sensor every $15 \mathrm{~min}$ (Carruthers et al. 2001). Instantaneous PPFD $\left(\mu \mathrm{mol} \mathrm{m}{ }^{-2} \mathrm{~s}^{-1}\right)$ integrated over a $1 \mathrm{~min}$ period was measured every 10 to 15 min throughout the entire experiment. All light loggers were calibrated against a standard light source. Water temperature was sourced from a regular monitoring site (Department of Environment and Conservation Western Australia unpubl. data) at $30^{\circ} 27^{\prime} \mathrm{S}, 115^{\circ} 03^{\prime} \mathrm{E}$ (WGS84) and $5 \mathrm{~m}$ water depth.

Seagrass biomass, density and morphology measures: Above-ground samples for biomass, density and morphology variables were pooled from 5 randomly selected $10 \times 10 \mathrm{~cm}$ units taken from within a $50 \times 50 \mathrm{~cm}$ quadrat (i.e. $0.05 \mathrm{~m}^{2}$ sample area) located randomly within the effective sampling area of each plot. The number of stems, clusters and leaves in each sample were counted to estimate their density. A cluster was defined as a group of leaves separated from the next cluster by visible stem. A leaf was counted if it had emerged from the sheath. One stem was randomly selected from each sample to take additional measures of leaf length and width (oldest leaf in cluster) and internode length (5 most recently produced internodes). Height of all stems was also measured. The number of leaves per cluster was counted for the entire sample. The whole sample was then separated into leaves and stems, all epiphytes removed, and each component dried separately at $60^{\circ} \mathrm{C}$ for $24 \mathrm{~h}$ before weighing. Canopy heights were calculated from the stem height data in the sample, and number of leaves or clusters per stem from the morphology data.
Growth measures: Leaf growth for the 1 to $2 \mathrm{wk}$ period prior to biomass sampling was estimated by tagging all leaf clusters $(\sim 30)$ on 6 stems using the leaf punch method of Short \& Duarte (2001), modified as per Mackey et al. (2007). Depending on the stems randomly selected, this yielded 10 to 30 tagged leaf clusters per plot. Leaf extension was calculated as the sum of all leaves that grew in a cluster.

Tissue carbon, nitrogen and carbohydrate content: Six stems with associated below-ground rhizome material were collected separately from within each plot. Leaves were sampled from the mid-canopy, 20 to $40 \mathrm{~cm}$ above the sediment surface. Samples of living leaf and rhizome were scraped free of epiphytes, dried and ground in a mill grinder. Samples were analysed for carbon (\% dry weight, DW), nitrogen (\% DW), $\delta^{13} \mathrm{C}$ and $\delta^{15} \mathrm{~N}$ using a mass spectrometer ANCA-NT interfaced with a 20-20 isotope ratio mass spectrometer (Europa Scientific). Isotope signatures were determined by comparison with laboratory reference material previously calibrated against IAEA or NIST standard reference materials with a precision of $<0.1 \%$. Soluble sugars (\% DW) and starch (\% DW) were analysed by colorimetric determination $(420 \mathrm{~nm})$ with an amylase pre-digest to convert the starch to glucose (Yemm \& Willis 1954).

Statistical analysis. All data were analysed using a balanced, 3 factor [Intensity (I), Duration (D), Time (T); I and D fixed; T, random], fully orthogonal ANOVA. All data were tested for normality (KolmogorovSmironov goodness of fit test; Zar 1999) and heterogeneity (Cochran's test; Cochran 1951) and transformed if necessary. If, after transformations, the data were not normally distributed and the data were unimodal then it was assumed that due to the large number of samples the analysis would be robust to deviations from normality (Underwood 1997). If the variances were heterogeneous after transformation then there was an increased risk of a Type 1 error but, due to the large, balanced experimental design ANOVA is robust to this departure (Underwood 1997). However, as a precaution the significance level was set to 0.01 in these circumstances. Fishers LSD post-hoc tests were carried out if there were significant factors or interactions in the ANOVA (Quinn \& Keough 2002).

To test for significant differences between experimental light climates, we compared the hours of saturating irradiance $\left(H_{\text {sat }}\right)$ of each treatment. $H_{\text {sat }}$ was defined as hours with PPFD above $55 \mu \mathrm{mol}$ photon $\mathrm{m}^{-2} \mathrm{~s}^{-1}$, based on the saturating irradiance for Amphibolis griffithii (Masini \& Manning 1997). In each plot for which light data were available, 10 days were randomly chosen from each $\mathrm{T} \times \mathrm{D} \times \mathrm{I}$ treatment and the mean $H_{\text {sat }}$ for those days tested for significant differences among treatments in a fully orthogonal design. 
Table 1. Light data (photosynthetic photon flux density, PPFD) for all shading treatments (control and shaded plots, 3 experimental durations, 2 timings). $H_{\text {sat }}$ : the saturating irradiance for photosynthesis was set at $55 \mu \mathrm{mol} \mathrm{m}^{-2} \mathrm{~s}^{-1}$ (Masini \& Manning 1997).

Temperature: mean water temperature over the duration of experiment

\begin{tabular}{|c|c|c|c|c|c|c|c|}
\hline $\begin{array}{l}\text { Timing \& } \\
\text { duration }\end{array}$ & $\begin{array}{c}\text { Intensity of } \\
\text { shading }\end{array}$ & \multicolumn{2}{|c|}{ Total PPFD } & $\begin{array}{l}\text { Avg. instant. PPFD } \\
\left(\mu \mathrm{mol} \mathrm{m} \mathrm{m}^{-2} \mathrm{~s}^{-1}\right)\end{array}$ & \multicolumn{2}{|c|}{ Time above $H_{\text {sat }}$} & $\begin{array}{c}\text { Temperature } \\
\left({ }^{\circ} \mathrm{C}\right)\end{array}$ \\
\hline \multicolumn{8}{|c|}{ Post-summer } \\
\hline \multirow[t]{3}{*}{$3 \mathrm{mo}$} & Control & 1942 & 100 & 218 & 962 & 100 & 21.7 \\
\hline & Moderate & 317 & 16 & 35 & 435 & 45 & \\
\hline & High & 95 & 5 & 11 & 118 & 12 & \\
\hline \multirow[t]{3}{*}{$6 \mathrm{mo}$} & Control & 3258 & 100 & 191 & 1821 & 100 & 20.0 \\
\hline & Moderate & 553 & 17 & 31 & 706 & 39 & \\
\hline & High & 207 & 6 & 12 & 299 & 16 & \\
\hline \multirow[t]{3}{*}{$9 \mathrm{mo}$} & Control & 6690 & 100 & 277 & 2805 & 100 & 19.6 \\
\hline & Moderate & 1252 & 19 & 52 & 1361 & 49 & \\
\hline & High & 64 & 10 & 27 & 590 & 21 & \\
\hline \multicolumn{8}{|c|}{ Post-winter } \\
\hline \multirow[t]{3}{*}{$3 \mathrm{mo}$} & Control & 3996 & 100 & 508 & 1098 & 100 & 18.7 \\
\hline & Moderate & 715 & 18 & 93 & 641 & 58 & \\
\hline & High & 447 & 11 & 59 & 286 & 26 & \\
\hline \multirow[t]{3}{*}{$6 \mathrm{mo}$} & Control & 8051 & 100 & 481 & 2329 & 100 & 19.9 \\
\hline & Moderate & 1128 & 14 & 68 & 1371 & 59 & \\
\hline & High & 691 & 9 & 39 & 627 & 27 & \\
\hline \multirow[t]{3}{*}{$9 \mathrm{mo}$} & Control & 9416 & 100 & 383 & 3215 & 100 & 19.8 \\
\hline & Moderate & 1256 & 13 & 51 & 1803 & 56 & \\
\hline & High & 784 & 8 & 29 & 803 & 25 & \\
\hline
\end{tabular}

Table 2. Amphibolis griffithii. ANOVA testing for significant effects of Timing (T), Duration (D) and Intensity (I) of shading on biomasses (leaves, stems, algal epiphytes) and morphological parameters (leaf density, cluster density, leaf length, leaf width, leaves per cluster, cluster growth, leaf extension, 80 percentile canopy height, internode length). ${ }^{1}$ Not homogenous, significance level set to $\mathrm{p}<0.01 .{ }^{2} 9$ mo duration not included. ${ }^{3}$ Time 0 treatment not included. ${ }^{\#}$ df either 1 or 2 due to omission of time 0 and/or time 9 mo from dataset (see variables marked 2, 3); interaction terms similarly affected. ${ }^{\text {Ln}}$ Ln transformed, Sqrt Square root transformed. ${ }^{* * *} \mathrm{p}<0.001,{ }^{* *} \mathrm{p}<0.01,{ }^{*} \mathrm{p}<0.05$

\begin{tabular}{|c|c|c|c|c|c|c|c|c|c|c|c|}
\hline \multirow[t]{2}{*}{ Factor } & \multirow[t]{2}{*}{$\mathrm{df}$} & & $\mathrm{p}$ & $F$ & $\mathrm{p}$ & $F$ & $\mathrm{p}$ & & $\mathrm{p}$ & & $\mathrm{p}$ \\
\hline & & \multicolumn{2}{|c|}{$\begin{array}{l}\text { Leaf } \\
\text { biomass }^{\text {Ln }}\end{array}$} & \multicolumn{2}{|c|}{$\begin{array}{c}\text { Stem } \\
\text { biomass }^{\text {Ln }}\end{array}$} & \multicolumn{2}{|c|}{$\begin{array}{l}\text { Algal epiphyte } \\
\text { biomass }^{\text {Ln }}\end{array}$} & \multicolumn{2}{|c|}{$\begin{array}{c}\text { Leaf } \\
\text { density }\end{array}$} & \multicolumn{2}{|c|}{$\begin{array}{l}\text { Cluster } \\
\text { density }\end{array}$} \\
\hline $\mathrm{T}$ & 1 & 0.56 & & 2.84 & & 14.9 & $* * *$ & 0.24 & & 0.09 & \\
\hline D & 3 & 41.3 & ** & 3.54 & & 2.34 & & 16.3 & * & 11.2 & * \\
\hline I & 2 & 62.8 & * & 33.1 & * & 18.7 & & 25.0 & * & 21.7 & * \\
\hline $\mathrm{T} \times \mathrm{D}$ & 3 & 3.09 & * & 3.23 & * & 9.70 & $* * *$ & 4.33 & $* *$ & 7.03 & $* * *$ \\
\hline $\mathrm{T} \times \mathrm{I}$ & 2 & 2.26 & & 0.29 & & 3.23 & $*$ & 3.09 & $*$ & 2.98 & \\
\hline $\mathrm{D} \times \mathrm{I}$ & 6 & 44.0 & $* * *$ & 1.00 & & 3.74 & & 15.9 & ** & 9.00 & $* *$ \\
\hline \multirow[t]{2}{*}{$\mathrm{T} \times \mathrm{D} \times \mathrm{I}$} & 6 & 0.08 & & 0.33 & & 0.86 & & 0.93 & & 1.64 & \\
\hline & & \multicolumn{2}{|c|}{$\begin{array}{c}\text { Leaf } \\
\text { length }^{1,2,3}\end{array}$} & \multicolumn{2}{|c|}{$\begin{array}{c}\text { Leaf } \\
\text { width }^{1,2,3}\end{array}$} & \multicolumn{2}{|c|}{$\begin{array}{l}\text { Leaves/ } \\
\text { cluster }^{2}\end{array}$} & \multicolumn{2}{|c|}{$\begin{array}{l}\text { Cluster } \\
\text { growth }^{\mathrm{Ln}, 2,3}\end{array}$} & \multicolumn{2}{|c|}{$\begin{array}{l}\text { Leaf } \\
\text { extension }^{\mathrm{Ln}, 2,}\end{array}$} \\
\hline $\mathrm{T}$ & 1 & 7.28 & * & 0.03 & & 13.9 & *** & 9.42 & $* *$ & 0.34 & \\
\hline D & 2 & 1.25 & & 238 & * & 4.67 & & 50.7 & & 2.3 & \\
\hline I & 1 or $2^{\#}$ & 0.04 & & 1.04 & & 17.5 & & 36.2 & ${ }^{*}$ & 285 & $* *$ \\
\hline $\mathrm{T} \times \mathrm{D}$ & 2 & 4.04 & & 0.04 & & 11.4 & $* * *$ & 31.9 & *** & 48.3 & *** \\
\hline $\mathrm{T} \times \mathrm{I}$ & 2 & 1.98 & & 2.32 & & 3.41 & & 2.99 & & 0.22 & \\
\hline $\mathrm{D} \times \mathrm{I}$ & 4 & 1.21 & & 2.46 & & 11.5 & ** & 2.99 & & 4.40 & \\
\hline \multirow[t]{2}{*}{$\mathrm{T} \times \mathrm{D} \times \mathrm{I}$} & 4 & 1.03 & & 1.45 & & 1.92 & & 9.92 & $* * *$ & 3.80 & $* *$ \\
\hline & & \multicolumn{2}{|c|}{$\begin{array}{l}\text { 80th percentile } \\
\text { canopy height }^{\text {Sqrt }}\end{array}$} & \multicolumn{2}{|c|}{$\begin{array}{l}\text { Internode } \\
\text { length }^{\mathrm{Ln}}\end{array}$} & & & & & & \\
\hline $\mathrm{T}$ & 1 & 3.32 & & 3.32 & & & & & & & \\
\hline D & 3 & 2.62 & & 2.62 & & & & & & & \\
\hline I & 2 & 17.7 & & 17.7 & & & & & & & \\
\hline $\mathrm{T} \times \mathrm{D}$ & 3 & 4.69 & $* *$ & 4.69 & $* *$ & & & & & & \\
\hline $\mathrm{T} \times \mathrm{I}$ & 2 & 0.77 & & 0.77 & & & & & & & \\
\hline $\mathrm{D} \times \mathrm{I}$ & 6 & 5.47 & * & 5.47 & * & & & & & & \\
\hline $\mathrm{T} \times \mathrm{D} \times \mathrm{I}$ & 6 & 0.76 & & 0.76 & & & & & & & \\
\hline
\end{tabular}



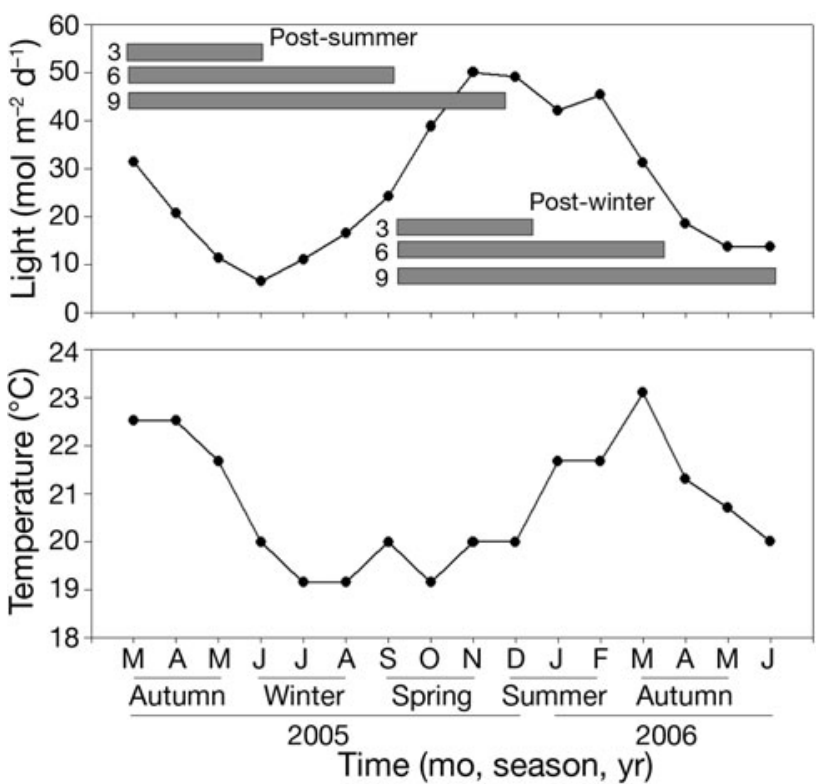

Fig. 1. (a) Ambient light and (b) temperature during the experimental periods

\section{RESULTS}

\section{Light treatments and temperature}

Moderate shading plots received 13 to $19 \%$ of ambient PPFD during the experiment and high shading plots received 5 to $11 \%$ of ambient PPFD (Table 1). ANOVA indicated that the hours of saturating irradiance were significantly different among treatments (Table 2), pairwise comparisons confirming all 3 intensities were significantly different to each other $(\mathrm{p}<$ 0.05 in all cases). Post-summer plots had the lowest absolute and average instantaneous PPFD measured during daylight (Table 1; Fig. 1) since they were applied during autumn-winter when ambient PPFD was low. These plots also had the lowest hours of saturating irradiance. Average water temperature ranged from $18.7^{\circ} \mathrm{C}$ in the 3 mo post-winter treatment to $21.7^{\circ} \mathrm{C}$ in the 3 mo post-summer treatment (Table 1 ). Thus, plants shaded at the end of summer were entering a period of declining PPFD but relatively high temperature while those shaded post-winter were entering a period of increasing PPFD but relatively low temperatures (Fig. 1).

\section{Leaf biomass, density and morphology}

Leaf biomass declined dramatically in post-summer treatments, with both moderate and high shading having lower leaf biomass than controls, but not different to each other (Fig. 2a). Moderate shading produced
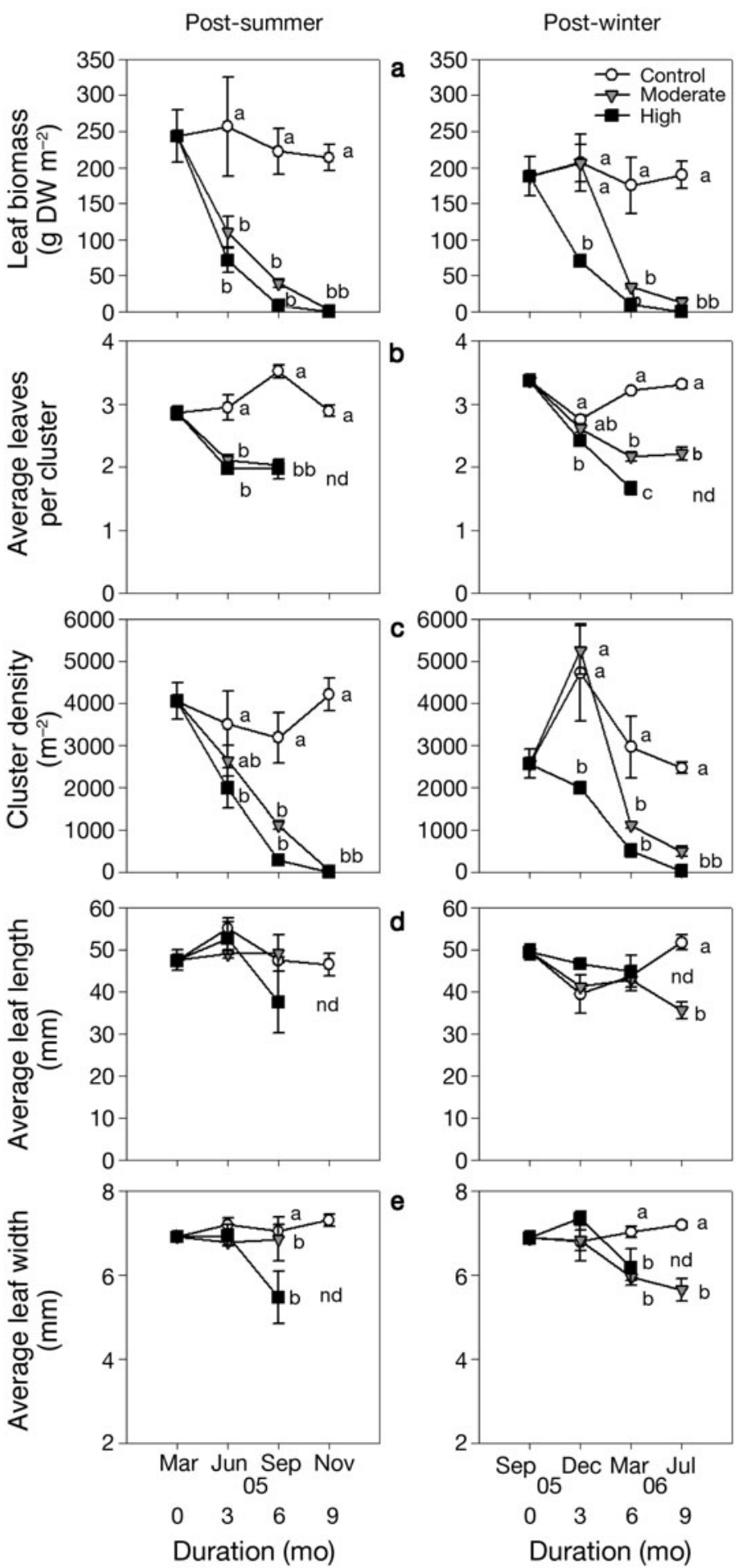

Fig. 2. Amphibolis griffithii. Leaf and cluster characteristics (means $\pm \mathrm{SE}_{;} \mathrm{n}=5$ ) following different intensities, durations and timing of shading. Left: Post-summer; right: post-winter treatments. (a) Leaf biomass, (b) leaves per cluster, (c) cluster density, (d) leaf length (e) leaf width. Shared letters indicate no significant difference. $n d=$ no data (too few leaves to determine the measure) 


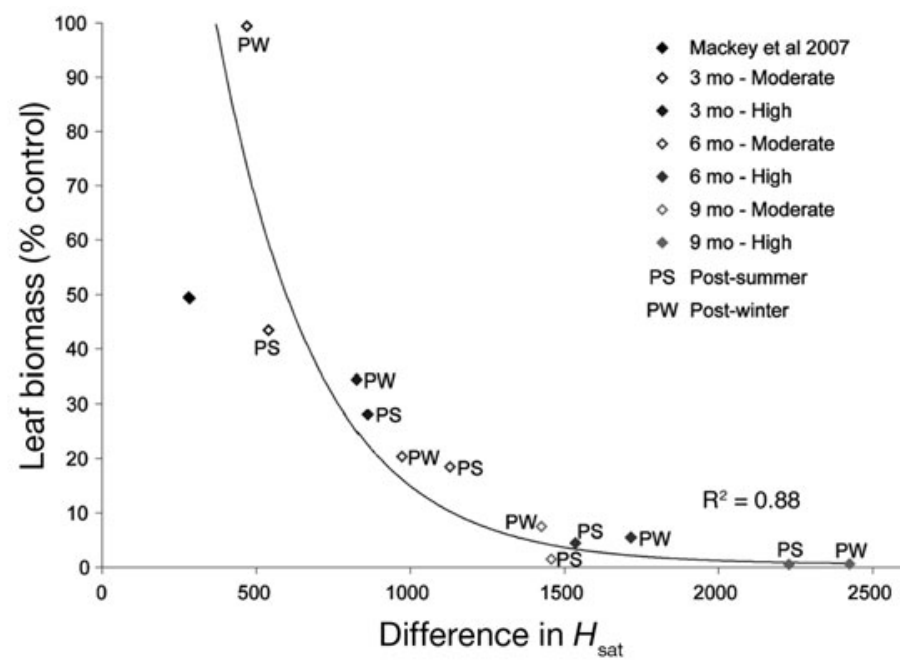

Fig. 3. Amphibolis griffithii. Relationship between shading (the total number of hours of saturating irradiance less than the controls, difference $H_{\text {sat }}$ ) and the loss of leaf biomass

$57 \%$ loss of leaf biomass after 3 mo, $82 \%$ after 6 mo and $99 \%$ after $9 \mathrm{mo}$, relative to the control (Fig. 2a). High shading resulted in 72, 96 and $100 \%$ loss relative to controls after 3, 6 and 9 mo, respectively. These general responses contrast post-winter treatments (Fig. $2 \mathrm{a})$, where moderate shading had no effect on leaf biomass after $3 \mathrm{mo}$; there was a subsequent decline of $81 \%$ and $93 \%$ after 6 mo and 9 mo (Fig. 2a). High shading post-winter and post-summer had similar effects on leaf biomass: a decline of 66, 94 and $100 \%$ relative to the controls after $3 \mathrm{mo}, 6 \mathrm{mo}$ and $9 \mathrm{mo}$, respectively). These patterns in leaf biomass loss were reflected in the significant $\mathrm{D} \times \mathrm{I}$ interaction (Table 2).

Plotting leaf loss as a function of the imposed shading can be problematic in long-term experiments, since the same percentage shading in one season may produce a different absolute PPFD than in another season with different ambient light conditions. Thus, in terms of absolute light levels, the reduction treatments may not be analagous. Therefore, we re-analysed the data expressing the treatments as difference in hours of saturating irradiance the plants experienced relative to control plots. This is a more meaningful physiological descriptor of the stress experienced by the plants. Loss of leaf biomass was negatively exponentially related to the change in $H_{\text {sat }}$ relative to controls $\left(\mathrm{r}^{2}=\right.$ 0.88; Fig. 3).

Loss of leaf biomass was caused by loss of whole leaves within clusters and whole clusters of leaves (Fig. 2b,c), both these variables showing similar responses to leaf biomass. Following moderate shading post-summer, leaves per cluster declined (com- pared to control) after 3 mo from 2.9 to 2.0 , and after 6 mo from 3.5 to 2.0 (Table 2, Fig. 2b) and could not be calculated after 9 mo as no or too few clusters were present. In contrast, when moderately shaded postwinter, number of leaves per cluster did not differ after $3 \mathrm{mo}$, but by 6 mo it had declined from 3.2 to 2.2. High shading always resulted in fewer leaves per cluster, irrespective of duration or time of year (Fig. 2b).

The number of leaves per stem and leaf density mirrored the responses of leaf biomass (Table 2), indicating that the loss of leaf biomass was relatively even across stems and the meadow. The change in cluster density (Fig. 2c) was similar to, but slower than, that of leaf biomass, indicating that initially leaves were lost from clusters and, with increased intensity and duration of PPFD reduction, whole clusters were lost. Leaf morphology was not affected by the intensity of shading (Table 2, Fig. 2d,e).

\section{Stem and epiphyte biomass}

Changes in leaf biomass dominated the change in total above-ground biomass (leaf + stem). Only high shading resulted in a loss of stem biomass which, after 9 mo, declined by $54 \%$ relative to controls post-summer and by $44 \%$ post-winter (Fig. $4 \mathrm{a}$; Table 2). Stem density followed the same trend (Table 2). With all leaves lost, the above-ground biomass attributable to stems was about $100 \mathrm{~g} \mathrm{DW} \mathrm{m}^{-2}$.

Algal epiphyte biomass declined by $80 \%$ (relative to controls) after 3 mo of moderate shading post-summer and by $90 \%$ after 6 mo (Fig. 4 b, Table 2). The pattern differed when shading was imposed post-winter, with no significant effect of moderate shading after 3 mo, though biomass had declined by $70 \%$ by 6 mo. High shading resulted in a loss of algal epiphyte biomass at all durations (post-summer: $90 \%$ loss after 3 mo and 95\% after 6 mo; post-winter: $70 \%$ loss after 3 mo and $90 \%$ after 6 mo). The stems held 68 to $97 \%$ of all algal epiphyte biomass, indicating that the loss of algal biomass was not simply a function of loss of leaf substratum.

\section{Canopy height and internode length}

The canopy height (80th percentile) was sustained by the persistent stems until 6 mo of shading, when necrosis and abrasion of the tips resulted in a decline from about $57 \pm 4 \mathrm{~cm}$ to about $45 \pm 2 \mathrm{~cm}$ in the moderate and high shaded plots (Fig. 4c, Table 2).

Internodes of shaded plants were the same as or longer than those of control plants but with no consistent pattern over durations or intensities of shading 
(Table 2, Fig. 4d). Post-summer high shade treatment had longer internodes than the controls after 3 mo $(6.9 \pm 0.5$ vs. $5.5 \pm 0.3 \mathrm{~mm})$ and after $6 \mathrm{mo}(6.7 \pm 0.7 \mathrm{vs}$. $5.4 \pm 0.3 \mathrm{~mm}$ ) but not after $9 \mathrm{mo}$, while the moderately shaded plants only differed to controls at 6 mo $(7.3 \pm$ 0.5 vs. $5.4 \pm 0.3 \mathrm{~mm}$ ). Post-winter there was a significant difference only after $9 \mathrm{mo}$, when the high treatment $(4.2 \pm 0.6 \mathrm{~mm})$ was lower than the moderate $(5.2 \pm$ $0.3 \mathrm{~mm})$ and control $(5.7 \pm 0.4 \mathrm{~mm})$.
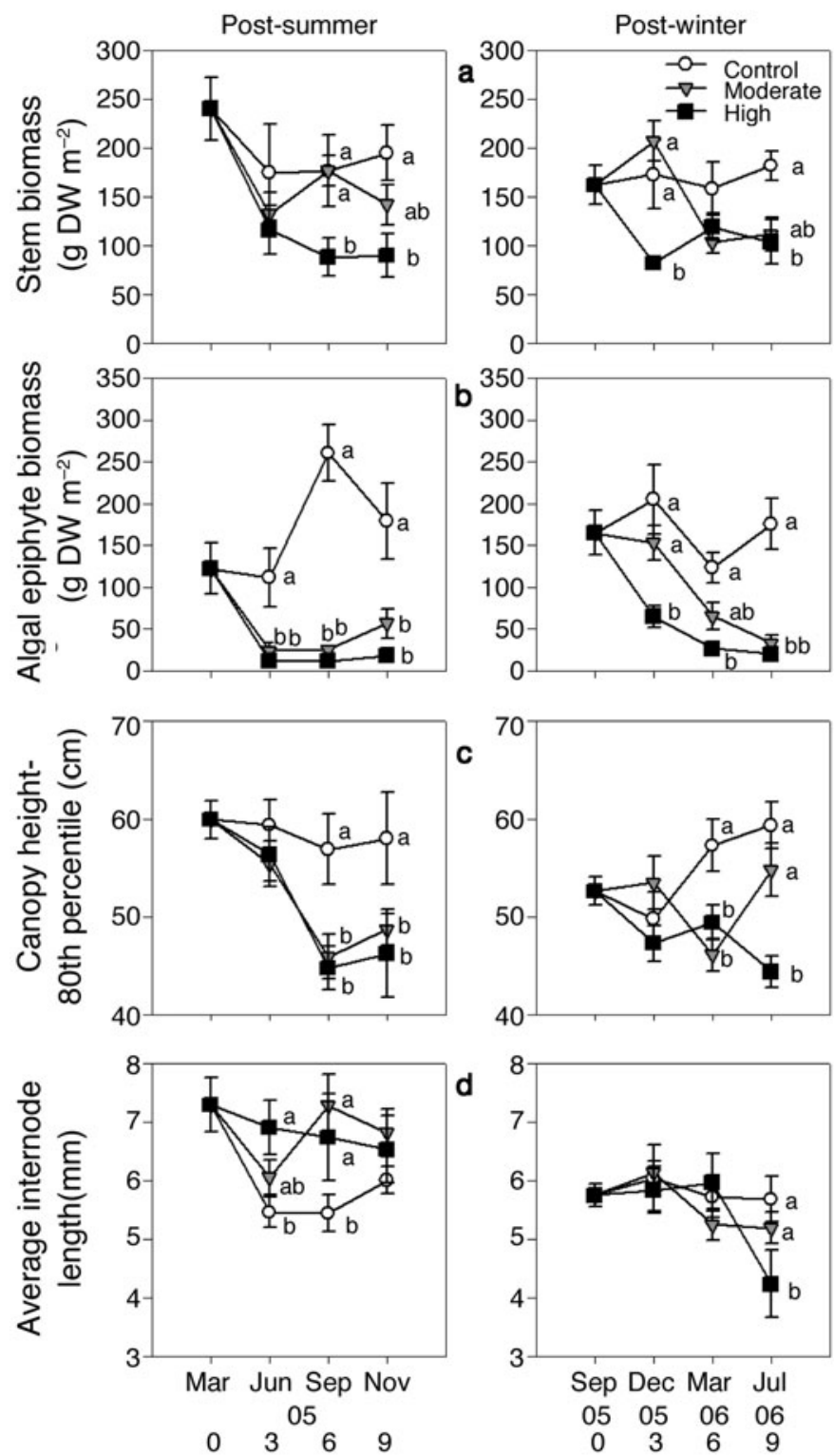

Duration (mo)

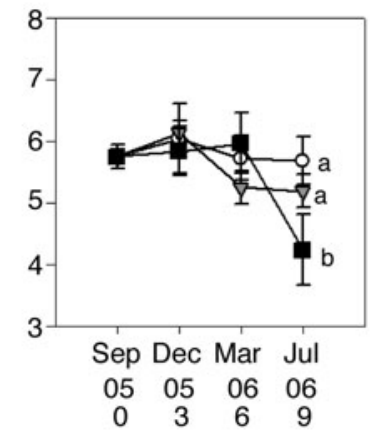

Duration (mo)

Fig. 4. Amphibolis griffithii. Stem and algal epiphyte biomass characteristics (means $\pm \mathrm{SE}_{i} \mathrm{n}=5$ ) following shading. Left: post-summer; right: post-winter treatments. (a) Stem biomass, (b) algal epiphyte biomass, (c) canopy height, (d) internode length. Shared letters indicate no significant difference
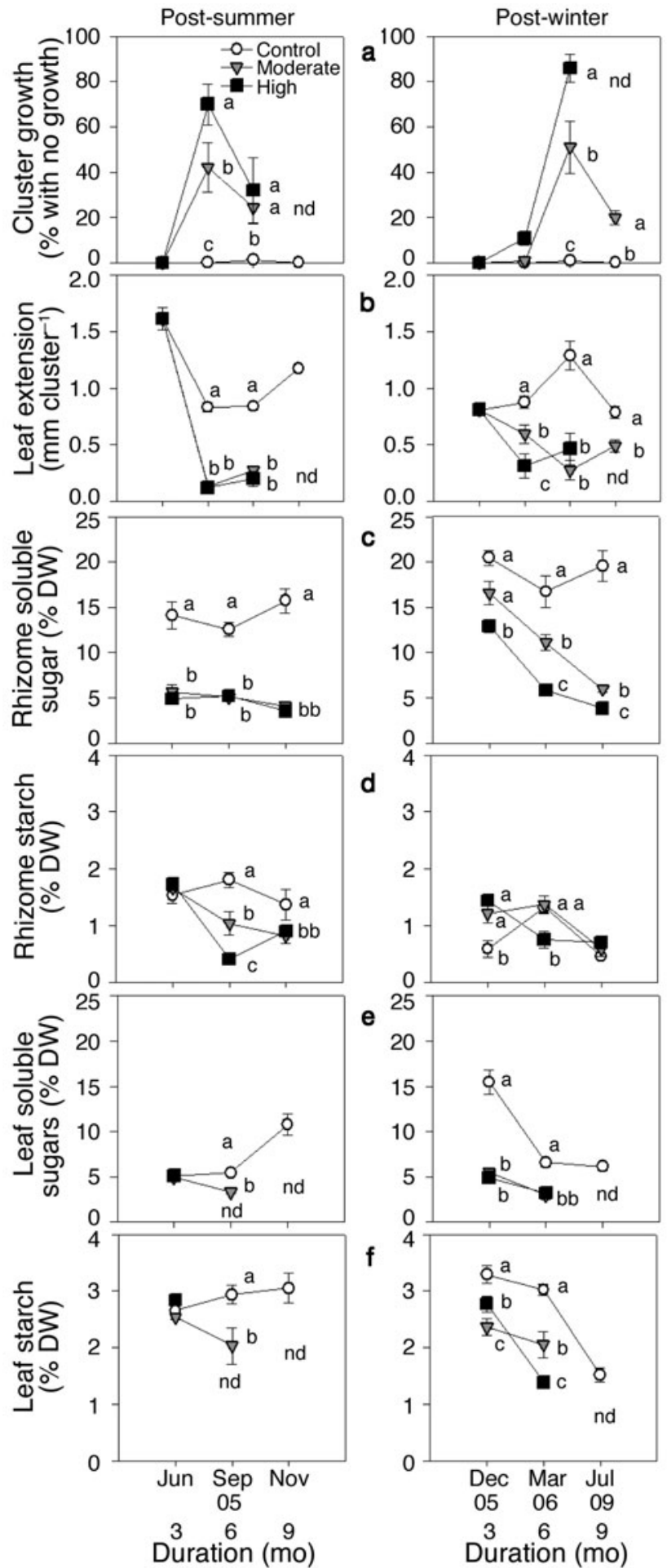

Fig. 5. Amphibolis griffithii. Growth and carbohydrate characteristics (means $\pm S E ; n=5$ ) following shading. Left: postsummer; right: post-winter treatments. (a) Cluster growth, (b) leaf extension rate, (c) rhizome soluble sugars. (d) rhizome starch (e) leaf soluble sugars, (f) leaf starch. Shared letters indicate no significant difference. nd = no data (too few leaves to determine the measure) 

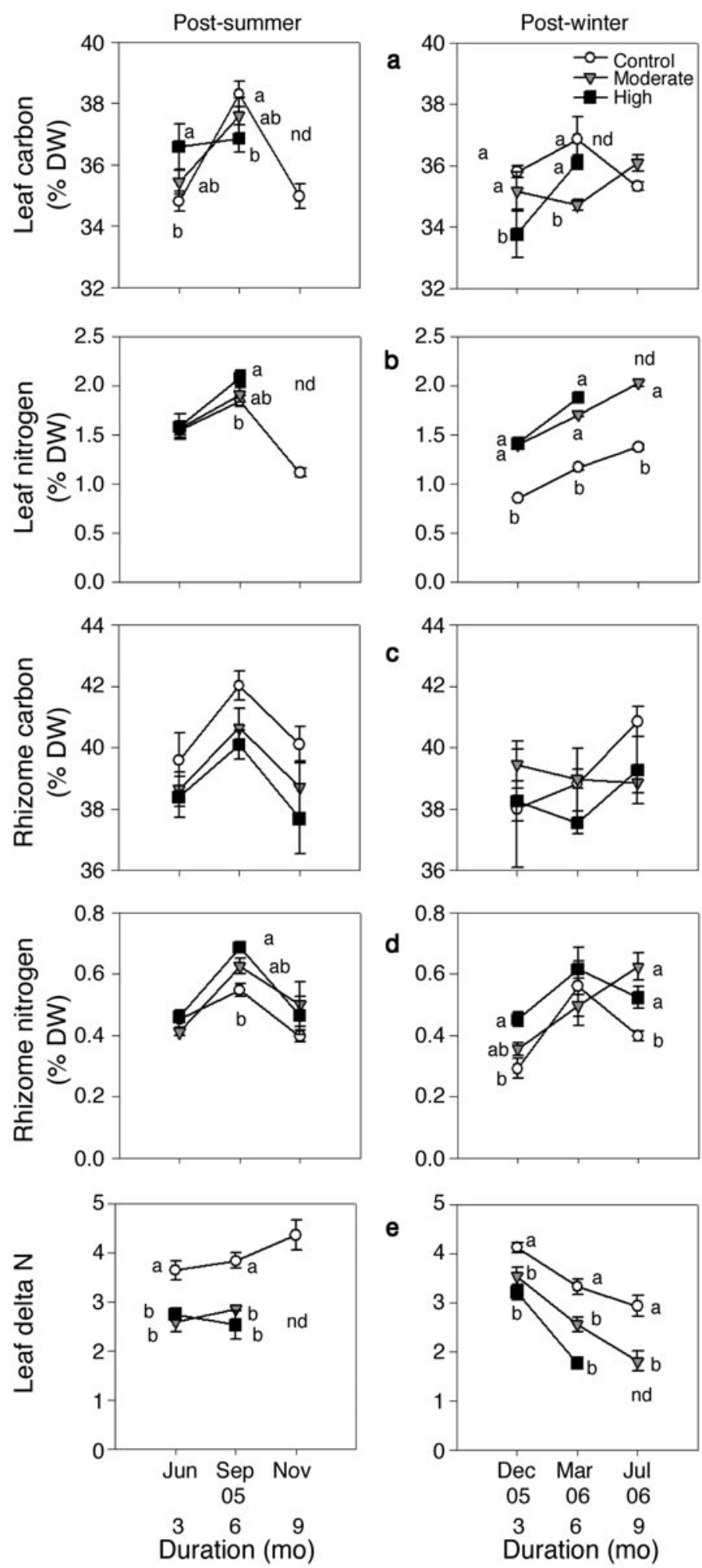

Fig. 6. Amphibolis griffithii. Nutrient characteristics (means \pm $\mathrm{SE} ; \mathrm{n}=5$ ) following shading. Left: post-summer; right: postwinter treatments. (a) Leaf carbon (b) leaf nitrogen (c) rhizome carbon (d) rhizome nitrogen, (e) leaf $\delta^{15} \mathrm{~N}$ value. Shared letters indicate no significant difference. nd = no data (too few leaves to determine the measure)

\section{Growth and physiology}

There was a significant effect of shading on the growth of leaves within clusters, with clusters not growing at all (Fig. 5a) and reduced leaf extension in those that did grow (Fig. 5b). Post-summer, many clusters did not grow after 3 mo (moderate: $42 \%$ of clusters; high: $70 \%$ ) and the leaf extension rates in those that did grow were $85 \%$ lower than in controls. After 6 mo shading fewer clusters did not grow (moderate shading: $24 \%$, high shading: $32 \%$ ), though there were far fewer clusters and the leaf extension rate remained low. As there were no or too few leaves left after 9 mo, leaf growth was not calculated. Post-winter treatment showed a similar response, but the onset was slower, with significant differences in the number of clusters growing not observed until $6 \mathrm{mo}$, though leaf extension rates of shaded plants were lower at all times.

In control plants, soluble sugars accounted for up to $20 \%$ of rhizome and up to $15 \%$ in leaf DW (Fig. 5c,e), while starch accounted for $2 \%$ of rhizome and $3 \%$ of leaf DW (Fig. 5d,f). There were mostly significant, but varying, effects of shading on all forms of carbohydrates (Table 3). Post-summer, plants subjected to either shading had lowered sugar content in rhizomes to about $5 \%$ DW after 3 mo, which was maintained thereafter (Fig. 5c). Starch content in rhizomes and leaves declined significantly after 6 mo shading (Fig. 5d,e,f). Post-winter shading produced a more gradual decline in carbohydrates.

Carbon content $(\% \mathrm{C})$ of leaves was significantly affected by shading, though the response was not consistent with intensity, duration or timing (Table 3, Fig. 6a). Nitrogen content $(\% \mathrm{~N})$ of leaves was significantly higher than controls in the post-winter moderate and high shading treatments, demonstrating the significant interactive effect of time $\times$ intensity (Table 3 , Fig. 6b). There was no effect of shading on total rhizome C or N (Table 3, Fig. 6c,d).

Content of $\delta^{15} \mathrm{~N}$ in leaves was approximately $30 \%$ lower after shading compared to the control in the post-summer treatments (Table 3, Fig. 6e). Post-winter, $\delta^{15} \mathrm{~N}$ decreased after moderate (and high) shading: by $15 \%(25 \%)$ after $3 \mathrm{mo}$, by $25 \%(50 \%)$ after $6 \mathrm{mo})$. There was no effect of shading on the mean $\delta^{13} \mathrm{C}$ of leaves (means ranging from $-11.1 \pm 0.4$ to $-15.0 \pm$ $2.5 \%$ o) $\delta^{13} \mathrm{C}$ of rhizome $(-9.8 \pm 1.0$ to $-12.6 \pm 1.3 \%$ o $)$ and $\delta^{15} \mathrm{~N}$ rhizome $(1.6 \pm 0.4$ to $3.2 \pm 0.5 \%$; Table 3$)$.

\section{DISCUSSION}

\section{Intensity, duration and timing of light reduction}

The physiological and morphological changes induced in Amphibolis griffithii by different intensities, 
Table 3: Amphibolis griffithii. ANOVA testing for significant effects of timing (T), duration (D) and intensity (I) of shading on carbohydrate and nutrient parameters of leaves (nitrogen, $\delta^{15} \mathrm{~N}$, carbon, $\delta^{13} \mathrm{C}$ ), rhizomes (sugars, starch, $\delta^{15} \mathrm{~N}$, carbon, $\delta^{13} \mathrm{C}$ ), leaf sugars (after 3 and $6 \mathrm{mo}$ ), and leaf starch (after 3 and $6 \mathrm{mo}$ ), ${ }^{1}$ Not homogenous, significance level set to $\mathrm{p}<0.01 .{ }^{2} 9 \mathrm{mo}$ duration treatment not included. ${ }^{3}$ Time 0 treatment not included. ${ }^{\text {Ln }}$ Ln transformed; ${ }^{* * *} \mathrm{p}<0.001,{ }^{* *} \mathrm{p}<0.01,{ }^{*} \mathrm{p}<0.05$

\begin{tabular}{|c|c|c|c|c|c|c|c|c|c|}
\hline \multirow{3}{*}{$\begin{array}{l}\text { Factor } \\
\mathrm{T}\end{array}$} & \multirow{3}{*}{$\begin{array}{r}\mathrm{df} \\
1\end{array}$} & \multirow{2}{*}{\multicolumn{2}{|c|}{$\begin{array}{c}F \quad c \quad p \\
\text { Leaf nitrogen }\end{array}$}} & \multirow{2}{*}{\multicolumn{2}{|c|}{$\begin{array}{lr}F & p \\
\text { Leaf } \delta^{15} \mathrm{~N}^{2,3}\end{array}$}} & $F$ & $\mathrm{p}$ & \multirow{2}{*}{\multicolumn{2}{|c|}{$\begin{array}{l}F \\
\text { Leaf } \delta^{13} C^{2,3}\end{array}$}} \\
\hline & & & & & & \multicolumn{2}{|c|}{ Leaf carbon ${ }^{2,3}$} & & \\
\hline & & 71.1 & $* * *$ & 0.26 & & 16.5 & $* * *$ & 2.11 & \\
\hline $\mathrm{D}$ & 1 & 68.7 & & 0.75 & & 9.09 & & 1.42 & \\
\hline I & 2 & 1.74 & & 24.6 & $*$ & 0.84 & & 5.69 & \\
\hline $\mathrm{T} \times \mathrm{D}$ & 1 & 0.80 & & 36.2 & $* * *$ & 2.75 & & 4.76 & * \\
\hline $\mathrm{T} \times \mathrm{I}$ & 2 & 19.2 & $* * *$ & 2.16 & & 2.68 & & 0.10 & \\
\hline $\mathrm{D} \times \mathrm{I}$ & 2 & 12.1 & & 15.9 & & 0.30 & & 0.70 & \\
\hline \multirow[t]{2}{*}{$\mathrm{T} \times \mathrm{D} \times \mathrm{I}$} & 2 & 0.25 & & 0.19 & & 8.84 & $* *$ & 0.94 & \\
\hline & & \multicolumn{2}{|c|}{ Rhizome sugars ${ }^{\mathrm{Ln}, 3}$} & \multicolumn{2}{|c|}{ Rhizome starch ${ }^{3}$} & \multicolumn{2}{|c|}{ Rhizome nitrogen ${ }^{\mathrm{Ln}, 3}$} & \multicolumn{2}{|c|}{ Rhizome $\delta^{15} \mathrm{~N}^{1,3}$} \\
\hline $\mathrm{T}$ & 1 & 146 & $* * *$ & 23.9 & $* * *$ & 3.22 & & 19.1 & $* * *$ \\
\hline $\mathrm{D}$ & 2 & 2.44 & & 2.77 & & 4.32 & & 7.4 & \\
\hline I & 2 & 21.7 & $*$ & 0.23 & & 5.84 & & 0.08 & \\
\hline $\mathrm{T} \times \mathrm{D}$ & 2 & 19.4 & $* * *$ & 8.95 & $* * *$ & 6.98 & $* *$ & 2.06 & \\
\hline $\mathrm{T} \times \mathrm{I}$ & 2 & 12.6 & $* * *$ & 13.1 & $* * *$ & 1.71 & & 2.54 & \\
\hline $\mathrm{D} \times \mathrm{I}$ & 4 & 4.12 & & 95.8 & $* * *$ & 1.39 & & 0.61 & \\
\hline \multirow[t]{2}{*}{$\mathrm{T} \times \mathrm{D} \times \mathrm{I}$} & 4 & 3.79 & $* *$ & 0.17 & & 1.79 & & 2.02 & \\
\hline & & \multicolumn{2}{|c|}{ Rhizome carbon ${ }^{1,3}$} & \multicolumn{2}{|c|}{ Rhizome $\delta^{13} \mathrm{C}^{3}$} & & & & \\
\hline $\mathrm{T}$ & 1 & 2.71 & & 21.7 & $* * *$ & & & & \\
\hline $\mathrm{D}$ & 2 & 0.33 & & 0.03 & & & & & \\
\hline I & 2 & 5.02 & & 0.13 & & & & & \\
\hline $\mathrm{T} \times \mathrm{D}$ & 2 & 6.03 & * & 6.29 & $* *$ & & & & \\
\hline $\mathrm{T} \times \mathrm{I}$ & 2 & 0.79 & & 0.52 & & & & & \\
\hline $\mathrm{D} \times \mathrm{I}$ & 4 & 1.55 & & 0.82 & & & & & \\
\hline \multirow[t]{2}{*}{$\mathrm{T} \times \mathrm{D} \times \mathrm{I}$} & 4 & 0.52 & & 0.89 & & & & & \\
\hline & & \multicolumn{2}{|c|}{ Leaf sugars $(3 \mathrm{mo})^{\mathrm{Ln}}$} & \multicolumn{2}{|c|}{ Leaf starch (3 mo) } & \multicolumn{2}{|c|}{ Leaf sugars (6 mo) } & \multicolumn{2}{|c|}{ Leaf starch (6 mo) } \\
\hline $\mathrm{T}$ & 1 & 43.9 & $* * *$ & 1.54 & & 1.14 & & 0.06 & \\
\hline I & 2 & 1.02 & & 1.45 & & 15.4 & & 921 & * \\
\hline $\mathrm{T} \times \mathrm{I}$ & 2 & 36.7 & $* * *$ & 6.06 & $* *$ & 3.76 & & 0.02 & \\
\hline
\end{tabular}

durations and timing of shading were qualitatively similar to effects observed in other seagrasses (e.g. Lee \& Dunton 1997, Collier et al. 2009). However, the combination of 3 factors in a single experimental design has highlighted the significance of the inter-action of these factors, especially with respect to the effect of timing of shading.

While timing of shading affected the nature and magnitude of the plant responses, we did not replicate this experiment, and so cannot infer a 'seasonal' effect. Notwithstanding this, the results are consistent with a seasonal effect of light reduction. It is predicted that plants initially respond to stress through physiological adjustments and later, if the stress continues or increases, through morphological adjustments (Waycott et al. 2005). We noted that 3 mo of moderate shading imposed at the end of summer resulted in morphological, growth and physiological changes, but when imposed at the end of winter did not induce morphological changes. These effects can be explained by the interaction of 3 variables: the imposed light reductions; ambient light and temperature at the time of light reduction; and the inherent photo-physiology of the plants. For Amphibolis griffithii, the saturating irradiance for photosynthesis $\left(I_{\mathrm{K}}\right)$ varies with water temperature (Masini \& Manning 1997) (least at $13^{\circ} \mathrm{C}$, highest at $21^{\circ} \mathrm{C}$ ). Treatments imposed at the end of summer spanned autumn and winter, a period of declining photoperiod and PPFD but high water temperature (Fig. 1) and, therefore, light requirements. Conversely, plants shaded at the end of winter were entering a period of increasing ambient light intensities, receiving more 
than double the PPFD of plants shaded at the end of summer, and had lower light requirements (Masini \& Manning 1997). Thus, treatments which nominally appear similar (3 mo of moderate shading) actually represent significantly different stresses due to the interaction of the shading and the seasonal change in ambient light climate and temperature, as reflected in the amount of time the plant experiences saturating irradiance, $I_{k}$ (Table 1, Fig. 3). This helps to explain why plants shaded post-winter displayed only physiological adaptation to the shading, as this timing created a low stress level (greater time above $I_{k}$ ) while those shaded post-summer showed morphological changes since their actual stress was greater at that time.

This greater susceptibility to shading that we observed in the autumn-winter period is consistent with the suggestion that Amphibolis griffithii would be most susceptible to light reductions during winter (Carruthers \& Walker 1997). These authors estimated that the storage reserves of $A$. griffithii were less than those required to support one day's respiratory demand, and suggested that the lower ambient light conditions in winter diminish the potential for fixing new carbon, making the plant more susceptible to unfavourable conditions. The most obvious morphological response of the plants to shading was leaf loss. Leaves can have a respiratory demand 4 to 7 times higher than the below-ground parts (Fourqurean \& Zieman 1991, Masini et al. 1995). The loss of shoots while retaining below-ground storage tissues has previously been interpreted as an adaptation to maintain a positive carbon balance (Touchette \& Burkholder 2000, Mackey et al. 2007, Collier et al. 2009).

Using changes in $H_{\text {sat }}$ as a measure of stress on plants can be problematic since very high light intensities, while saturating photosynthesis, may induce photo-inhibition. Here, we are confident this is not the case. Masini \& Manning (1997) examined the P-I (photosynthesis-irradiance) relationships of Amphibolis. griffithii and other seagrasses up to light intensities approximately comparable to the maximum observed in our controls (i.e. $>1000 \mu \mathrm{mol} \mathrm{m} \mathrm{m}^{-2} \mathrm{~s}^{-1}$ ). They did not report any photo-inhibition in $A$. griffithii and only reported photo-inhibition for 1 species, Posidonia sinuosa, at PPFDs above $2000 \mu \mathrm{mol} \mathrm{m} \mathrm{m}^{-2} \mathrm{~s}^{-1}$. Furthermore, the strong $\left(r^{2}=0.88\right)$ relationship between the change in hours of saturating irradiance and leaf loss suggests that the plant responses we observed are related to difference in the hours of saturating light they experience and this is most likely due to the interaction of shading and ambient light availability.

Despite our descriptors 'moderate' and 'high', both shading treatments caused comparatively high reductions in light. Nonetheless, these are typical within the sediment plumes resulting from commercial dredging operations. Furthermore, it is clear that moderate and high shading resulted in different effects on the seagrass and so, while both are severe, even at these high levels of light reduction, the differences are biologically meaningful. Moderate shading, which displayed the strong effects of timing, represented $>80 \%$ reduction of ambient PPFDs and so, while our conclusion regarding timing is constrained to 'moderate' shading impacts, it is applicable to all but the most severe of impacts.

\section{Indicators of reduced light availability}

The second aim of the study was to identify potential indicators of sub-lethal light stress. In considering potential indicators of reduced light availability to Amphibolis griffithii, we have focussed on those variables that showed a relatively rapid response (i.e. by the first sampling time) and showed a relatively consistent response across times of year and intensities and durations of light reduction. Out of 8 variables that showed consistent and early responses, 2 were different to the controls at the first sampling time: leaf extension rate and leaf $\delta^{15} \mathrm{~N}$. Other parameters showed a significant response within 3 mo of high shading but not always in the moderate shading treatments: leaf biomass; algal epiphyte biomass; leaf density; cluster density; leaves per cluster; and rhizome sugars. Other than the density and biomass variables, which capture the whole canopy, application of these variables in monitoring would require consideration of the potential for self-shading to confound the results, and measurements would need to be made from a consistent position within the canopy profile.

Mackey et al. (2007) examined a smaller set of parameters but at greater frequency (monthly over $3 \mathrm{mo}$ ). That earlier work on Amphibolis griffithii indicates that some of the variables shown here already respond after 1 to 2 mo (e.g. leaves per cluster, leaf extension, rhizome sugars). Hence we assume that the variables we have identified as early indicators of sub-lethal stress are likely to respond at significantly shorter timescales than the 3 mo interval used here.

Those 2 physiological variables that showed a consistent response to light reduction (leaf extension rate and carbohydrate concentrations) have been reported as doing so in other seagrasses (e.g. Lee \& Dunton 1997, Longstaff et al. 1999), though there were some exceptions. The lack of response in leaf $\delta^{13} \mathrm{C}$ values contrasts other findings on shading e.g. Collier et al. (2009). This may reflect leaves coming from the selfshaded portion of the canopy where additional shading had little effect on the light climate. However, data for the top of the canopy (not included here) reveal the same lack of response. It is possible that any new leaf 
growth is coming from fixed $\mathrm{C}$ mobilised from the rhizome, thus preventing any change in $\delta^{13} \mathrm{C}$ associated with discrimination during fixation of new C. Similarly, it was surprising to see no etiolation response in the leaves. Collier et al. (2009) have also shown an absence of leaf elongation during prolonged periods of extreme shading, though this response was not consistent over different depths. In the case of Amphibolis griffithii, it is possible that the 'etiolation' response was seen in the longer inter-node length of stems in some treatments. Given the long stems and very short leaves of $A$. griffithii, inter-node extension may be more effective in moving photosynthetic tissue into higher light conditions than leaf extension.

Values of $\delta^{15} \mathrm{~N}$ have rarely been measured in seagrasses in relation to light availability, though Grice et al. (1996) found no effect in several tropical seagrass species. Here, we saw reduced $\delta^{15} \mathrm{~N}$ in shaded plants, similar to studies in terrestrial angiosperms. Plants grown in low light invest more $\mathrm{N}$ in light harvesting components (Evans \& Poorter 2001) while in high light environments investment is in electron carriers and Calvin cycle enzymes (Evans 1989). Relative to the bulk $\delta^{15} \mathrm{~N}$ of cells, proteins are enriched while pigments are depleted (Werner \& Schmidt 2002). Therefore, a greater investment in pigments under reduced light conditions could produce lower $\delta^{15} \mathrm{~N}$ values. We did not measure pigments in the leaves; Mackey et al. (2007), however, showed increased chlorophyll following reduction of light availability. The response of $\delta^{15} \mathrm{~N}$ to shading is, therefore, consistent with a light-limitation induced mechanism though, because many other factors could influence plant $\delta^{15} \mathrm{~N}$ signals, caution would need to be used in applying this in a monitoring programme.

\section{Susceptibility to reduced light availability}

Our final hypothesis was that, relative to larger seagrasses, Amphibolis griffithii would have a lower capacity to withstand severe shading. The widely accepted functional-form model for seagrasses (Walker et al. 1999) suggests that, relative to 'large' seagrass species such as Posidonia spp, Amphibolis spp. are more susceptible to disturbance, due to their thinner rhizomes and associated lower capacity to store carbohydrate reserves. Carruthers \& Walker (1997) suggested that the difference in below-ground storage reserves explained the loss of Amphibolis spp. in areas where Posidonia spp survived effluent flows.

When shaded for 3 mo after winter, we observed $66 \%$ loss of leaf biomass under high, but $0 \%$ under moderate shading. At similar shading, the same time of year and similar depth (4 m), Posidonia sinuosa had $68 \%$ loss of above ground biomass under high shading $(<10 \%$ of ambient), much the same as we observed for Amphibolis griffithii, but $57 \%$ loss under moderate shading, significantly more than we observed for A. griffithii (Collier et al. 2009). Neverauskas (1988) showed that when shaded in early winter $P$. sinuosa persisted for as long as 6 mo with no shoot loss, again comparable to our observation for A. griffithii. Thus, there is no clear evidence to support the hypothesis that $A$. griffithii is more susceptible to shading than $P$. sinuosa.

This apparently counter-intuitive result might be explained by the ratios of leaf to carbohydrate storage tissue. Seagrass leaves have higher respiratory demand than rhizomes (Fourqurean \& Zieman 1991, Masini et al. 1995) and in low light the high ratio AG:BG of Amphibolis griffithii (1.8 to 2.0) should disadvantage it relative to Posidonia sinuosa (0.8 to 1.1 ; Table 4 ), as would the ratio of leaf biomass to rhizome carbohydrate reserves (25 to 35, compared with 6 to 12 for $P$. sinuosa). However, anatomically the stems of A. griffithii are vertical, above-ground rhizomes. Assuming similar carbohydrate reserves as their below-ground analogues, the ratio of leaf biomass: carbohydrate reserve in A. griffithii is estimated to be 2 to 4 (Table 4), lower than $P$. sinuosa. We have not measured the carbohydrate reserves in the stems, but this would clearly be worth pursuing as it may explain why A. griffithii was no less susceptible to shading than $P$. sinuosa.

Table 4. Amphibolis griffithii and Posidonia sinuosa. Ratios of biomass above ground to below ground (AG:BG) and AG to carbohydrate store (AG:CHO)

\begin{tabular}{|c|c|c|c|c|c|c|c|c|c|}
\hline \multirow[t]{2}{*}{ Species } & \multicolumn{3}{|c|}{ AG Biomass (gDW m ${ }^{-2}$ ) } & \multicolumn{2}{|c|}{ BG Biomass (gDW m² $\left.{ }^{-2}\right)$} & \multirow[t]{2}{*}{$\mathrm{AG}: \mathrm{BG}^{\mathrm{b}}$} & \multicolumn{2}{|c|}{ Carbohydrate } & \multirow[t]{2}{*}{$\mathrm{AG}: \mathrm{CHO}^{\mathrm{f}}$} \\
\hline & Total & Leaf & Stem & Total & Rhizome & & $\begin{array}{c}\text { Rhizome } \\
\text { conc. }^{\mathrm{C}}\left(\mathrm{mg} \mathrm{g}{ }^{-}\right.\end{array}$ & $\begin{array}{l}\text { Store } \\
\left(g^{c} m^{-2}\right)\end{array}$ & \\
\hline A. griffithii & $623-737^{a}$ & $326-452^{\mathrm{a}}$ & $290-300$ & $185-229^{a}$ & $135-171^{\mathrm{a}}$ & $1.8-2.0^{\mathrm{b}}$ & $190-205^{\mathrm{a}}$ & $26-35$ & $9-18$ \\
\hline P. sinuosa & $645-698^{\mathrm{d}}$ & $645-698^{\mathrm{d}}$ & 0 & $584-785^{\mathrm{d}}$ & $380-391^{\mathrm{d}}$ & $0.8-1.1$ & $160-280^{\mathrm{e}}$ & $61-110$ & $6-12$ \\
\hline $\begin{array}{l}\text { A. griffithii } \\
\text { with stem }\end{array}$ & $623-737^{a}$ & $326-452^{\mathrm{a}}$ & $290-300$ & $185-229^{a}$ & $135-171^{\mathrm{a}}$ & $1.8-2.0^{\mathrm{b}}$ & $190-205^{a}$ & $122-152$ & $2-4$ \\
\hline
\end{tabular}




\section{Conclusions}

Our study addressed the effects of intensity, duration and timing of shading on Amphibolis griffithii, and revealed complex interactions among these factors. Increased shading generally resulted in increased effects on A. griffithii though the timing of light reduction is important in determining plant response, at least for those intensities and durations of shading which are not extreme. This likely reflects the interaction of imposed light reductions with ambient light climate and temperature and the plant's light requirements at that time of year. Extrapolation of results from shading experiments conducted at a single time of year, which has been the norm, should, therefore, be made with caution. We also conclude that $A$. griffithii is no more susceptible to shading than larger seagrasses such as Posidonia species, possibly due to the ratio of rhizome carbohydrate stores (below- and above-ground) to leaf biomass. Finally, several physiological and morphological variables have the potential to serve as indicators of sub-lethal light reduction for $A$. griffithii, including $\delta^{15} \mathrm{~N}$ of leaves and leaf extension rate.

Acknowledgements. We thank: R. Masini for his assistance in initiating this research and the fruitful discussions along the way; P. Quintana for his help in implementing the experimental work; the numerous volunteers who helped with fieldwork; D. Walker for helpful comments on a draft manuscript; and 3 anonymous reviewers who made very useful suggestions. This research was funded by the Western Australian Government's Strategic Research Fund for the Marine Environment and the Geraldton Port Authority.

\section{LITERATURE CITED}

Abal EG, Loneragan N, Bowen P, Perry CJ, Udy JW, Dennison WC (1994) Physiological and morphological responses of the seagrass Zostera capricorni Aschers to light-intensity. J Exp Mar Biol Ecol 178:113-129

Bulthuis DA (1983) Effects of in situ light reduction on density and growth of the seagrass Heterozostera tasmanica (Martens ex Aschers.) den Hartog in Western Port, Victoria, Australia. J Exp Mar Biol Ecol 67:91-103

Carruthers TJB, Walker DI (1997) Light climate and energy flow in the seagrass canopy of Am phibolis griffithii (J.M. Black) den Hartog. Oecologia 109:335-341

Carruthers TJB, Longstaff B, Dennison W, Abal E, Aioi K (2001) Measurement of light penetration in relation to seagrass. In: Short FT, Coles RG (eds) Global Seagrass Research Methods. Elsevier Science BV, Amsterdam, p 369-392

Cochran WG (1951) Testing a linear relation among variances. Biometrics 7:17-32

> Collier CJ, Lavery PS, Masini RJ, Ralph PJ (2007) Morphological, growth and meadow characteristics of the seagrass Posidonia sinuosa along a depth-related gradient of light availability. Mar Ecol Prog Ser 337:103-115

Collier CJ, Lavery PS, Ralph PJ, Masini RJ (2009) Shadeinduced response and recovery of the seagrass Posidonia sinuosa. J Exp Mar Biol Ecol 370:89-103
Dennison WC, Alberte R (1982) Photosynthetic responses of Zostera marina L. (eelgrass) to in situ manipulations of light intensity. Oecologia 55:137-144

Duarte CM (2002) The future of seagrass meadows. Environ Conserv 29:192-206

Ducker SC, Foord JN, Knox BR (1977) Biology of Australian seagrasses: the genus Amphibolis C. Agardh (Cymodoceaceae). Aust J Bot 25:67-95

Evans JR (1989) Partitioning of nitrogen between and within leaves grown under different irradiances. Aust J Plant Physiol 16:533-548

Evans JR, Poorter H (2001) Photosynthetic acclimation of plants to growth irradiance: the relative importance of specific leaf area and nitrogen partitioning in maximizing carbon gain. Plant Cell Environ 24:755-767

> Fourqurean JW, Zieman JC (1991) Photosynthesis, respiration and whole plant carbon budget of the seagrass Thalassia testudinum. Mar Ecol Prog Ser 69:161-170

Gordon DM, Grey KA, Chase SC, Simpson CJ (1994) Changes to the structure and productivity of a Posidonia sinuosa meadow during and after imposed shading. Aquat Bot 47:265-275

Green EP, Short FT (2003) World atlas of seagrasses. University of California Press, Berkeley, CA

> Grice AM, Loneragan NR, Dennison WC (1996) Light intensity and the interactions between physiology, morphology and stable isotope ratios infivespecies of seagrass. J Exp Mar Biol Ecol 195:91-110

> Lee KS, Dunton H (1997) Effects of in situ light reduction on the maintenance, growth and portioning of carbon resources in Thalassia testudinum Banks ex Konig. J Exp Mar Biol Ecol 210:53-73

Longstaff BJ, Dennison WC (1999) Seagrass survival during pulsed turbidity events: the effects of light deprivation on the seagrasses Halodule pinifolia and Halophila ovalis. Aquat Bot 65:105-121

- Longstaff BJ, Loneragan NR, O'Donohue MJ, Dennison WC (1999) Effects of light deprivation on the survival and recovery of the seagrass Halophila ovalis (R.Br.) Hook. J Exp Mar Biol Ecol 234:1-27

> Mackey P, Collier CA, Lavery PS (2007) Effects of experimental reduction of light availability on the seagrass Amphibolis griffithii. Mar Ecol Prog Ser 342:117-138

Marba N, Walker DI (1999) Growth, flowering, and population dynamics of temperate Western Australian seagrasses. Mar Ecol Prog Ser 184:105-118

> Masini RJ, Manning CR (1997) The photosynthetic responses to irradiance and temperature of four meadow-forming seagrasses. Aquat Bot 58:21-36

> Masini RJ, Cary JL, Simpson CJ, McComb AJ (1995) Effects of light and temperature on the photosynthesis of temperate meadow-forming seagrasses in Western Australia. Aquat Bot 49:239-254

> Neverauskas VP (1988) Response of a Posidonia community to prolonged reduction in light. Aquat Bot 31:361-366

> Orth RJ, Carruthers TJB, Dennison WC, Duarte CM and others (2006) A global crisis for seagrass ecosystems. Bioscience 56:987-996

Peralta G, Perez-Llorens J, Hernandez I, Vergara J (2002) Effects of light availability on growth, architecture and nutrient content of the seagrass Zostera noltii Hornem. J Exp Mar Biol Ecol 269:9-26

Quinn GP, Keough MJ 2002. Experimental design and data analysis for biologists. Cambridge University Press, Cambridge

Ralph PJ, Tomasko D, Seddon S, Moore K, Macinnis-Ng C (2006) Human impact on Seagrasses: contamination and 
eutrophication. In: Larkum AWD, Orth RJ, Duarte CM (eds) Seagrass Biology, Ecology and Conservation. Springer, Dordrecht, p 567-593

Ruiz JM, Romero J (2003) Effects of disturbances caused by coastal constructions on spatial structure, growth dynamics and photosynthesis of the seagrass Posidonia oceanica. Mar Pollut Bull 46:1523-1533

Short FT, Duarte C (2001) Methods for the measurement of seagrass growth and production. In: Short FT, Coles RG (eds) Global Seagrass Research Methods. Elsevier Science BV, Amsterdam, p 155-182

Touchette BW, Burkholder JM (2000) Overview of the physiological ecology of carbon metabolism in seagrasses. J Exp Mar Biol Ecol 250:169-205

Underwood AJ 1997. Experiments in ecology: their logical design and interpretation using analysis of variance. Cambridge University Press, Cambridge.

Editorial responsibility: Kenneth Heck $J$, Dauphin Island, Alabama, USA
Walker DI, McComb AJ (1992) Seagrass degradation in Australian coastal waters. Mar Pollut Bull 25:191-195

Walker D, Dennison W, Edgar G (1999) Status of Australian seagrass knowledge. In: Butler A, Jernakoff P (eds) Seagrass in Australia: strategic review and development of an R \& D plan. CSIRO Publishing, Collingwood, p 1-24

Waycott M, Longstaff BJ, Mellors J (2005) Seagrass population dynamics and water quality in the Great Barrier Reef region: a review and future research directions. Mar Pollut Bull 51:343-350

Werner RA, Schmidt HL (2002) The in vivo nitrogen isotope discrimination among organic plant compounds. Phytochemistry 61:465-484

Yemm EW, Willis AJ (1954) The estimation of carbohydrates in plant extracts by anthrone. J Biochem 57:508-514

Zar JH (1999) Biostatistical analysis. Prentice Hall, Upper Saddle River, NJ

Submitted: December 12, 2008; Accepted: July 24, 2009 Proofs received from author(s): October 28, 2009 